\title{
Gastric leiomyoma or gastric schwannoma: a diagnostic dilemma and the role of laparoscopic surgery
}

\author{
Francesk Mulita ำ , ${ }^{1}$ Theano Perri, ${ }^{1}$ Elias Liolis, ${ }^{2}$ Levan Tchabashvili ${ }^{3}$
}

${ }^{1}$ Department of General Surgery, University General Hospital of Patras Holy Mary the Help, Patras, Greece

${ }^{2}$ Department of Internal Medicine, Division of Oncology, University General Hospital of Patras Holy Mary the Help, Patras, Greece

${ }^{3}$ Department of Surgery, University General Hospital of Patras Holy Mary the Help, Patras, Greece

\section{Correspondence to}

Francesk Mulita;

oknarfmulita@hotmail.com

Accepted 14 February 2022
Check for updates

(C) BMJ Publishing Group Limited 2022. No commercial re-use. See rights and permissions. Published by BMJ.

To cite: Mulita F, Perri T,
Liolis E, et al. BMJ Case
Rep 2022;15:e247199.
doi:10.1136/bcr-2021-
247199

\section{DESCRIPTION}

A 62-year-old woman with type 2 diabetes, hypothyroidism and symptoms of dyspepsia for 2 months was referred to our surgical group after an abdominal ultrasound (US) revealed a $3.8 \mathrm{~cm}$ mass in the greater curvature of the stomach. During physical examination, she was completely asymptomatic denying no weight loss, no changes in diet or appetite, as well as normal gastrointestinal function. Abdominal contrast enhanced CT scan was performed and revealed a well defined, rounded soft tissue lesion of size $3.9 \mathrm{~cm} \times 3.5 \mathrm{~cm} \times 2.5 \mathrm{~cm}$ arising from the greater curvature of stomach (figure 1). Endoscopic US-guided fine needle aspiration (FNA) of the lesion was suggestive of leiomyoma. The patient was consented for the surgery. She underwent laparoscopic-assisted wedge gastrectomy using a $60 \mathrm{~mm}$ endoscopic stapler, and a complete resection with negative surgical margins (R0) was obtained (figure 2). She was started on a soft diet on postoperative day 4. Her postoperative recovery was uneventful, and she was discharged home on postoperative day 6 .

In the pathological study, characteristic histological findings for gastric schwannoma were detected. The tumour cells were negative for EMA, NF, desmin, ckit, DOG1, HMB45, calretinin and ALK. However, they were positive for S100 and SOX10 protein. The lack of ckit/DOG1 expression is rarely found in gastrointestinal stromal tumor (GIST) tumours. Based on histology and immunohistochemistry findings, the final diagnosis of gastric intramuscular schwannoma was considered.

Also known as neurinomas or neurilemmomas, schwannomas are benign slow-growing tumours originating from a Schwann cell sheath. ${ }^{1}$ They are rarely discovered in the gastrointestinal tract, with stomach being the most common site $(60 \%-$ $70 \%)$. Gastric schwannomas account only 0.2\% of all gastric tumours, arising from the body of the stomach $(50 \%)$, the antrum $(32 \%)$ or fundus $(18 \%) .^{2}$ Transformation to a malignant tumour is rare and it has only been seen in children. ${ }^{3}$ Based on a study with 51 cases of Gastric schwannoma (GS), these tumours ranged from 1 to $10.5 \mathrm{~cm}$ (median, $4.5 \mathrm{~cm}) .{ }^{4} \mathrm{~A}$ female predominance has been reported (female:male ratio of 4:1) and the neoplasm usually occurs between fifth and sixth decade of life. ${ }^{2}$ They are typically asymptomatic and incidental findings during diagnostic studies. ${ }^{4}$ Nevertheless, the very common presenting symptom is an episode of upper gastrointestinal (GI) bleeding associated

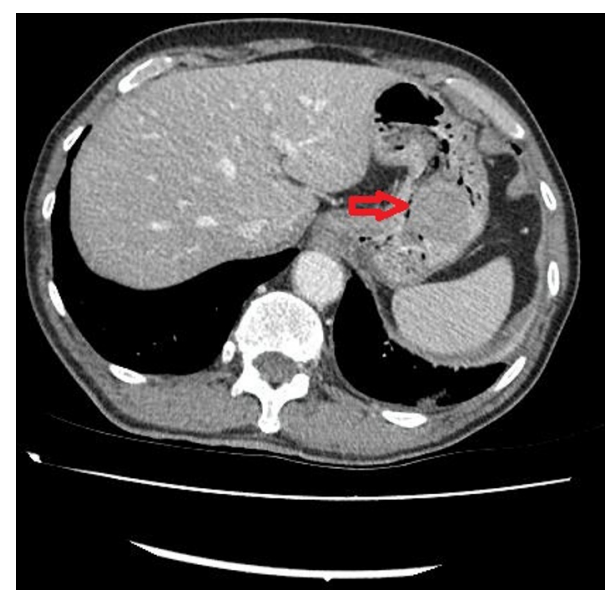

Figure 1 CT with intravenous contrast showing a well defined, rounded soft tissue mass arising from the greater curvature of the stomach, which does not enhance with intravenous contrast.

with abdominal pain. Other symptoms include gastroduodenal intussusception or palpable mass due to exophytic growth. ${ }^{25} \mathrm{CT}$, MRI or endoscopic

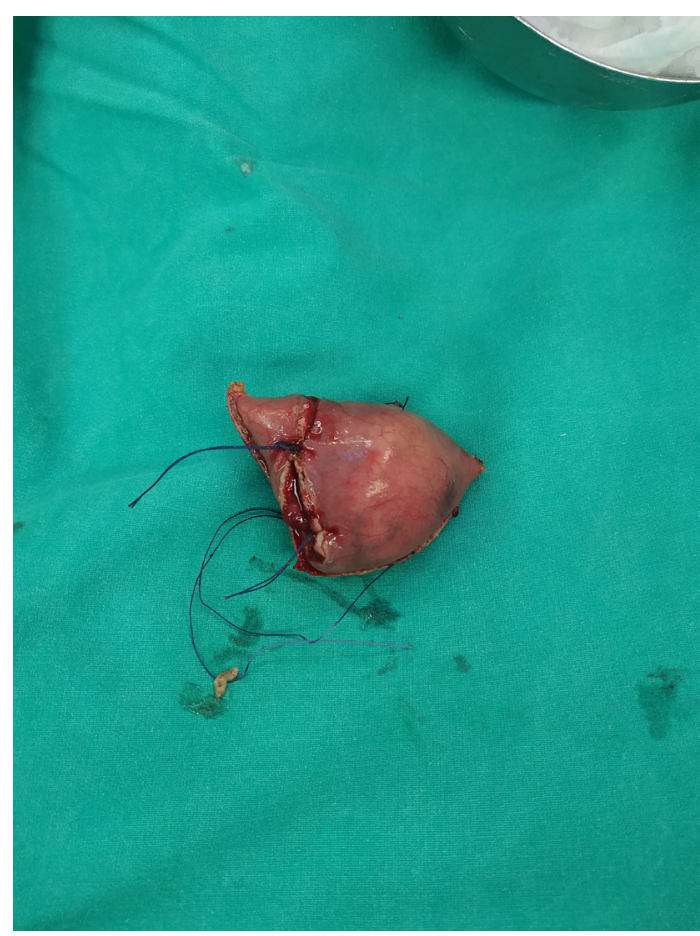

Figure 2 Resected gastric mass after laparoscopic surgery. 
ultrasonography can provide useful information, but gastrointestinal endoscopy is the principal diagnostic procedure. ${ }^{3}$ Pathological examination is the only way to confirm the diagnosis, while immunohistochemistry is used to differentiate gastric schwannomas from GISTs, leiomyomas, and GI autonomic nerve tumours GS are positive for $\mathrm{S} 100$ protein and vimentin and negative for CD34 and CD117. ${ }^{2}$

Because of the excellent prognosis, surgical resection with clear margins is the treatment of choice. Until now, most schwannomas had been removed with open surgery. However, laparoscopic resection is associated with the same favourable oncological outcome and is superior with respect to blood loss, hospital stay and postoperative pain. ${ }^{6}$ Recently, endoscopic modalities such as endoscopic submucosal resection and endoscopic full thickness resection have provided less invasive ways to treat GS. The appropriate surgical approach depends on tumour location and size, as well as the location of surrounding organs. ${ }^{7}$ As these tumours are benign, radiotherapy and chemotherapy are not needed. ${ }^{2}$ In 2015, a comprehensive review gathered 137 cases of gastric schwannomas and showed no cases of recurrence after a follow-up period ranging from 1 to 336 months. ${ }^{8}$ In accordance with these findings, a recent study showed a 5 -year cumulative

\section{Learning points}

- Gastric schwannomas are rare neoplasms of stomach which mimic clinically and radiologically with other gastric tumours (GISTs, leiomyomas).

- Only immunohistochemical study can differentiate these gastric tumours.

- Laparoscopic resection with negative surgical margin is recommended for gastric schwannomas. disease-free survival rate over 95\%. Incomplete margins are the main cause of recurrence. ${ }^{7}$ Regular follow-up with CT is not recommended. ${ }^{6}$

Contributors FM and LT had the idea of the study. FM and TP prepared the manuscript. FM and EL critically revised the manuscript. All authors accepted the final version of the manuscript.

Funding The authors have not declared a specific grant for this research from any funding agency in the public, commercial or not-for-profit sectors.

Competing interests None declared.

Patient consent for publication Consent obtained directly from patient(s).

Provenance and peer review Not commissioned; externally peer reviewed.

Case reports provide a valuable learning resource for the scientific community and can indicate areas of interest for future research. They should not be used in isolation to guide treatment choices or public health policy.

\section{ORCID iD}

Francesk Mulita http://orcid.org/0000-0001-7198-2628

\section{REFERENCES}

1 Singh A, Mittal A, Garg B, et al. Schwannoma of the stomach: a case report. J Med Case Rep 2016;10:4

2 Pu C, Zhang K. Gastric schwannoma: a case report and literature review. J Int Med Res 2020:48:030006052095782

3 Yoon HY, Kim CB, Lee YH, et al. Gastric schwannoma. Yonsei Med J 2008;49:1052-4.

4 Voltaggio L, Murray R, Lasota J, et al. Gastric schwannoma: a clinicopathologic study of 51 cases and critical review of the literature. Hum Pathol 2012;43:650-9.

5 Sreevathsa MR, Pipara G. Gastric schwannoma: a case report and review of literature. Indian J Surg Oncol 2015;6:123-6.

6 Cordera F, Salazar-Vitale A, Mejía-Sánchez E, et al. Laparoscopic resection of gastric schwannoma: a case report. Int J Surg Case Rep 2019;65:271-4.

7 Wu X, Li B, Zheng C, et al. Clinical characteristics and surgical management of gastrointestinal schwannomas. Biomed Res Int 2020;2020:1-6.

8 Hong X, Wu W, Wang M, et al. Benign gastric schwannoma: how long should we follow up to monitor the recurrence? A case report and comprehensive review of literature of 137 cases. Int Surg 2015;100:744-7.

Copyright 2022 BMJ Publishing Group. All rights reserved. For permission to reuse any of this content visit

https://www.bmj.com/company/products-services/rights-and-licensing/permissions/

BMJ Case Report Fellows may re-use this article for personal use and teaching without any further permission.

Become a Fellow of BMJ Case Reports today and you can:

- Submit as many cases as you like

- Enjoy fast sympathetic peer review and rapid publication of accepted articles

- Access all the published articles

- Re-use any of the published material for personal use and teaching without further permission

Customer Service

If you have any further queries about your subscription, please contact our customer services team on +44 (0) 2071111105 or via email at support@bmj.com.

Visit casereports.bmj.com for more articles like this and to become a Fellow 